\title{
EREBEA
}

Revista de Humanidades y Ciencias Sociales

Núm. 10 (2020), pp. 147-164

ISSN: 0214-0691

http://dx.doi.org/10.33776/erebea.v10i0.4957

\section{Mental Health and Interpersonal Relationships IMPACT IN PSYCHOLOgiCAL AND Physical Symptoms During Adolescence}

Tania Gaspar, PhD

CLISSIS/Universidade Lusíada de Lisboa, ISAMB/Universidade de Lisboa, Portugal

Gina Tomé, PhD

FMH/Universidade de Lisboa, ISAMB/Universidade de Lisboa, Portugal

SFRH/BPD/108637/2015

Ana Cerqueira, $\mathrm{PhD}$

FMH/Universidade de Lisboa, ISAMB/Universidade de Lisboa, Portugal

SFRH/BD/148403/2019

Fábio Botelho Guedes

FMH/Universidade de Lisboa, ISAMB/Universidade de Lisboa, Portugal

SFRH/BD/148299/2019

Marta Raimundo

CLISSIS/Universidade Lusiada de Lisboa, Portugal

Margarida Gaspar de Matos, $\mathrm{PhD}$

FMH/Universidade de Lisboa, ISAMB/Universidade de Lisboa e APPsyCI, ISPA,

Portugal

ABSTRACT

This article aims to understand and characterize the impact of factors of mental health and interpersonal relationships on physical and psychological symptoms in adolescents. It includes 8215 students, of which 4327 are girls (52.7\%), with an average age of 14.36 years $(S D=2.28)$ that participate in the study Health Behavior in School aged Children/HBSC. Descriptive statistics, ANOVA analysis and logistic regressions were performed for two dependent variables in study psychological symptoms and physical
RESUMEN

Este artículo tuvo como objetivo examinar el impacto de los factores de salud mental y de las relaciones interpersonales sobre los síntomas físicos y psicológicos en adolescentes. La muestra estuvo formada por 8215 estudiantes, de los cuales 4327 fueron niñas $(52,7 \%)$, con una edad media de 14,36 años (DT $=2,28$ ), que participaron en el estudio Health Behavior in School aged Children/HBSC. $\mathrm{Se}$ realizaron estadísticos descriptivos, ANOVA y regresiones logísticas para dos variables dependientes en este estudio: los 
symptoms. In general, girls show values in relation to physical and psychological symptoms, anxiety/stress and depression that are less positive when compared to boys. Older adolescents show values that are less positive in the same variables, except for anxiety/stress, which presents higher values in younger adolescents. Girls and older adolescents have lower positive values with regard to relationships with family, teachers and colleagues, than boys and younger adolescents. The female gender, higher values of depression followed by less support from the family contribute strongly to the explanation of psychological and physical symptoms. It is possible to verify that the variance explained by gender and by depression is higher in the case of psychological symptoms when compared to physical symptoms, and that the variance explained by family relationship is higher in the case of physical symptoms when compared with psychological symptoms. This study identifies a positive relationship between mental health (less physical and psychological symptoms, lower depression and lower anxiety) and more positive relationships with family, colleagues and teachers, as well as gender and age specificities. These results have important implications in terms of public policies for the family and the school contexts.

\section{KeYwords}

Mental health; interpersonal relationships; social support; physical and psychological symptoms; adolescents

Fecha de recepción: 24 de septiembre de 2020 Fecha de aceptación: 26 de octubre de 2020 síntomas psicológicos y los síntomas físicos. En general, las niñas mostraron valores de síntomas físicos y psicológicos, ansiedad / estrés y depresión que fueron menos positivos en comparación con los niños. Los adolescentes mayores mostraron asimismo valores menos positivos en dichas variables, excepto en la variable ansiedad / estrés, que presenta valores más altos en adolescentes más jóvenes. Las niñas y los adolescentes mayores tuvieron valores positivos más bajos con respecto a las relaciones con la familia, los maestros y los compañeros que los niños y los adolescentes más jóvenes. El género femenino, mayores valores de depresión y un menor apoyo de la familia contribuyeron fuertemente a la explicación de los síntomas psicológicos y físicos. La varianza explicada por género y por depresión fue mayor en el caso de síntomas psicológicos en comparación con los síntomas físicos, mientras que la varianza explicada por las relaciones familiares fue mayor en el caso de los síntomas físicos que en los síntomas psicológicos. Este estudio identifica una relación positiva entre la salud mental (menos síntomas físicos y psicológicos, y menor depresión y ansiedad) y relaciones más positivas con la familia, los compañeros y profesores, además de algunas diferencias por género y edad. Estos resultados tienen importantes implicaciones en términos de políticas públicas para el contexto familiar y escolar.

\section{Palabras Clave}

Salud mental; relaciones interpersonales; apoyo social; síntomas físicos y psicológicos; adolescentes. 


\section{INTRODUCTION}

In general, a large proportion of young people report themselves as healthy, happy, and satisfied with their life circumstances (Gaspar et al., 2012). However, it is estimated that around $20 \%$ of the adolescents experience significant stress situations at some point in their development, which raises questions about the long-term impact that this distress has on their future adjustment.

There is evidence that only a small proportion of adolescents with stress disorders receive treatment and that personal distress is related to negative school outcomes and overall adjustment (Allen \& McKenzie, 2015; Gaspar et al., 2009). Youth psychosocial development is influenced by individual and environmental/ contextual factors associated with the adolescents' well-being, of which school involvement and success are examples (Berger et al., 2011; Lewis et al., 2011).

There is evidence in the literature of the link between social relationships and health (Feeney \& Collins, 2014; Holt-Lunstad \& Uchino, 2015; Melrose et al., 2015; Thoits, 2011; Umberson \& Montez, 2010), insofar as the level of social integration is likely to influence physical and mental health and health behaviors (Umberson \& Montez, 2010).

Social support is understood as the social ties, the social integration, and the relationships between the individuals (Turner \& Brown, 2010). On the one hand, the existence of positive social relationships and support networks are factors that tend to arise associated with higher levels of satisfaction with life, self-esteem, happiness and well-being (Fuller-Iglesias et al., 2015; Gaspar \& Matos, 2017; Kong et al., 2014; Lee \& Goldstein, 2016; Rook, 2015). On the other hand, they also have a protective effect with regard to the development of depressive symptoms (Eom et al., 2012; Fuller-Iglesias et al., 2015; Liu et al., 2016; Nguyen et al., 2015; Tahir et al., 2015) and are associated with lower levels of psychological distress and negative affect (Nguyen et al., 2015).

Social support works as a protective factor in relation to the mental health and the effects of stress and as an element that promotes favorable behaviors and outcomes throughout the life cycle (Gaspar, Matos, Foguet et al., 2010; Lee \& Goldstein, 2016; Taylor et al., 2015; Turner \& Brown, 2010), contributing to a positive development. In this way, positive and supportive social relationships promote the achievement of positive outcomes (e.g. academic, behavioral, 
psychological) and protect the individual from negative outcomes (Varga \& Zaff, 2017).

Social support, including within the family, is a protective factor for human health (Hobfoll, 2002). The relationship between social support, mental health and quality of life must be seen from an ecological perspective once they involve a complex and multidimensional interconnection that includes psychological, social and demographic variables such as gender, marital status, age and socioeconomic status (Bronfenbrenner, 2005; Gaspar \& Matos, 2017; Gaspar, Matos, Ribeiro et al., 2010).

Social support is associated with the promotion of health and well-being, with the reduction of isolation and with the increase in life satisfaction. In addition, it attenuates the effects that result from the various difficulties that people face every day. Thus, the greater the perception of social support, the greater the presence of positive affect and, consequently, the greater the level of well-being. Therefore, this reflects a relationship between social support and well-being (Caprara \& Steca, 2005).

Family support networks followed by networks of friends provide the greatest support to the most types of families (Fontes et al., 2012). Related to the school context, the mental health is one of the many factors that can influence the academic achievement, either in a positive or negative way. During adolescence, the mind, the intellectual and the social skills are still in development (Mundia, 2003).

According to Hattie (2009), proximity and trust with teachers is among the factors that help students' learning. If teachers do not create a close relationship with their students, this will likely be reflected in their ability to develop their own relationships and interactions with peers, which can create a negative feeling in the school environment and in the wider community.

Armstrong et al. (2015) found the overriding need for explicit and structured guidance for educators on how to respond to children or adolescents' who present mental health problems. It seems to be of major importance that teachers are encouraged to be alert for warning signs warranting careful consideration or timely action, but strongly discouraged, even informally, to diagnose the adolescents. Thus, to manage young people successfully it is important for teachers to understand the dangerous effects and implications of poor mental health regarding teaching and learning (Mundia, 2013).

Relationships with peers also plays a very important role regarding the mental health and the well-being of the adolescents. According to Camacho et al. (2017), developing a good relationship with the peer group is an essential factor for the promotion of the youths' emotional well-being (Camacho et al., 2017; Tomé et al., 2018). Young people who have more positive school experiences with greater 
peer support, report better psychosocial adjustment, and tend to perceive a higher life satisfaction (Marques et al., 2015; Matos et al., 2017).

In addition to teachers, the peers, the family, and the whole school community have an essential role regarding the promotion of the adolescents' mental health. To increase the effectiveness of mental health prevention programs, it is very important to involve all the contexts that are present in the adolescent's daily life (Tomé et al., 2020).

In this way, this article aims to understand and characterize the impact that factors of mental health (anxiety/stress and depression) and interpersonal relationships (family support, relationship with teachers and with colleagues) have on the adolescent's physical and psychological symptoms.

\section{Method}

\section{PARTICIPANTS}

This specific work will include students from the 6th (30.7\%), 8th $(33.7 \%)$, 10th $(20.8 \%)$ and 12 th grades $(14.8 \%)$, with a total of 8215 students, of which 4327 are girls $(52.7 \%)$, with an average age of 14.36 years $(S D=2.28)$, from all over the continent, that participate in the study Health Behavior in School aged Children/HBSC (Inchley et al., 2016; Matos et al., 2015, 2018).

\section{INSTRUMENT AND PROCEDURE}

This work is integrated in the Health Behavior in School aged Children/ HBSC (Inchley et al., 2016; Matos et al., 2015, 2018), which is a survey carried out every 4 years in 48 countries, in collaboration with the World Health Organization [WHO], following an international protocol (Roberts et al., 2009). HBSC intends to study the behaviors of the adolescents in their life contexts and their influence in terms of health and well-being. It includes questions related to demographic aspects, family, school, friends, health, well-being, sexuality, food, leisure, sleep, physical activity, substance consumption, medication use, violence, use of technologies, migrants, and social participation. Portugal has been included since 1998 (www.aventurasocial.com).

In Portugal, the HBSC 2018 study was approved by the Ethics Committee and MIME (Monitoring of School Surveys). School groups agreed to participate, and informed consent was obtained from parents or legal guardians. Responses to the survey (online) were voluntary and anonymous.

\section{MEASURES AND VARIABLES}

In order to understand and characterize the impact that factors of mental health and interpersonal relationships have on the adolescent's physical and psychological symptoms, the following variables were considered: 


\begin{tabular}{|c|c|c|c|}
\hline \multicolumn{2}{|c|}{ Variables information } & Minimum & Maximum \\
\hline Psychological symptoms & $\begin{array}{l}\text { Variable composed of } 4 \text { questions } \\
\text { related to psychological symptoms } \\
\text { (e.g. sadness) }\end{array}$ & 4.00 & 20.00 \\
\hline Physical symptoms & $\begin{array}{l}\text { Variable composed of } 7 \text { questions } \\
\text { related to physical symptoms and } \\
\text { pain (e.g. headache) }\end{array}$ & 7.00 & 35.00 \\
\hline Anxiety, stress & $\begin{array}{l}\text { Variable composed of questions } \\
\text { related to anxiety and stress - } \\
\text { higher values refer to more stress } \\
\text { and anxiety }\end{array}$ & 1.00 & 5.00 \\
\hline Depression & $\begin{array}{l}\text { Variable composed of questions } \\
\text { related to depression - higher } \\
\text { values refer to more depression }\end{array}$ & 1.00 & 4.00 \\
\hline Relationship with teachers & $\begin{array}{l}\text { Variable composed of questions } \\
\text { related to the relationship with } \\
\text { teachers - higher values refer to } \\
\text { better relationship }\end{array}$ & 3.00 & 15.00 \\
\hline Relationship with colleagues & $\begin{array}{l}\text { Variable composes of questions } \\
\text { related to the relationship with } \\
\text { colleagues - higher values refer to } \\
\text { better relationship }\end{array}$ & 3.00 & 15.00 \\
\hline Family support & $\begin{array}{l}\text { Variable composes of questions } \\
\text { related to the family support - } \\
\text { higher values refer to higher fam- } \\
\text { ily support }\end{array}$ & 4.00 & 28.00 \\
\hline
\end{tabular}

Table 1. Composite variables and measures in study-HBSC protocol 2018 (Matos et al., 2018)

\section{DATA ANALYSIS}

Firstly, the descriptive statistics (mean and standard deviation) were calculated for all the variables under study. Secondly, through the Pearson correlation the relationships between these variables were calculated. Thirdly, gender and age differences were analyzed using ANOVA analysis. Finally, logistic regressions were performed for the two dependent variables in study (i.e. psychological symptoms and physical symptoms).

\section{Results}

According to Table 2, the participants reveal positive values regarding social support (i.e. relationship with family, teachers, and colleagues) and moderate/ low values of physical and psychological symptoms and depression. In terms of anxiety/stress the values are moderate, presenting an average of 2.76 in a range of 1 to 4 . 


\begin{tabular}{l|r|r|r|r} 
& \multicolumn{1}{|c|}{ Min. } & \multicolumn{1}{c|}{ Max. } & \multicolumn{1}{c|}{$M$} & \multicolumn{1}{c}{$S D$} \\
\hline Psychological symptoms & 4.00 & 20.00 & 15.26 & 4.17 \\
\hline Physical symptoms & 7.00 & 35.00 & 28.69 & 5.60 \\
\hline Anxiety_stress & 1.00 & 5.00 & 2.76 & .67 \\
\hline Depression & 1.00 & 4.00 & 1.80 & .55 \\
\hline Relationship with teachers & 3.00 & 15.00 & 11.28 & 2.52 \\
\hline Relationship with colleagues & 3.00 & 15.00 & 11.80 & 2.41 \\
\hline Family support & 4.00 & 28.00 & 23.87 & 6.45
\end{tabular}

Table 2. Descriptive statistics for the study variables

According to Table 3, all variables under study are correlated in a statistically significant way. The positive correlation $(r .40)$ between physical symptoms and psychological symptoms $(r=.63)$, the negative correlation between low level of psychological symptoms and anxiety/stress $(r=-.45)$ and depression $(r=-.55)$, the negative correlation between low level of physical symptoms and depression $(R=-$ $.44)$, and the positive correlation between anxiety/stress and depression $(r=.63)$ are highlighted.

Regarding the social relationships, the positive correlation between family support and low level of physical symptoms $(r=.30)$, low level of psychological symptoms $(r=.31)$ and the negative correlation between low level of family support with anxiety/stress $(r=.36)$ and depression ( $r=-.37)$ are highlighted. It should also be noted the positive correlation between the relationship with teachers and the relationships with colleagues $(r=.36)$.

\begin{tabular}{l|c|c|c|c|c|c} 
& 1 & 2 & 3 & 4 & 5 & 6 \\
\hline 1. Psychological symptoms & - & & & & & \\
\hline 2. Physical symptoms & $.63^{* * *}$ & - & & & & \\
\hline 3. Anxiety_stress & $-.45^{* * *}$ & $-.36^{* * *}$ & - & & & \\
\hline 4. Depression & $-.55^{* * *}$ & $-.44^{* * *}$ & $.63^{* * *}$ & - & & \\
\hline 5. Relationship with teachers & $.27^{* * *}$ & $.24^{* * *}$ & $-.25^{* * *}$ & $-.27^{* * *}$ & - & \\
\hline 6. Relationship with colleagues & $.24^{* * *}$ & $.20^{* * *}$ & $-.19^{* * *}$ & $-.25^{* * *}$ & $.36^{* * *}$ & - \\
\hline 7. Family support & $.31^{* * *}$ & $.30^{* * *}$ & $-.36^{* * *}$ & $-.37^{* * *}$ & $.25^{* * *}$ & $.19^{* * *}$
\end{tabular}

Table 3. Pearson correlations for the study variables Note. ${ }^{* * *} p<.001$

There are statistically significant differences between boys and girls regarding variables related to mental health and interpersonal relationships (Table 4). Girls present values regarding physical and psychological symptoms, anxiety/stress 
and depression that are less positive when compared to boys. The same profile is verified with respect to the relationships with family, teachers, and colleagues.

\begin{tabular}{l|r|r|r|r|r} 
& \multicolumn{2}{|c|}{ Male } & \multicolumn{2}{c|}{ Female } & \multirow{2}{*}{ F } \\
\hline & \multicolumn{1}{|c|}{$M$} & \multicolumn{1}{c|}{$S D$} & \multicolumn{1}{c}{$M$} & \multicolumn{1}{c}{$S D$} & \\
\hline Psychological symptoms & 16.27 & 3.71 & 14.35 & 4.35 & $450.31^{* * *}$ \\
\hline Physical symptoms & 29.93 & 4.95 & 27.57 & 5.91 & $374.45^{* * *}$ \\
\hline Anxiety_stress & 2.64 & .65 & 2.85 & .66 & $105.10^{* * *}$ \\
\hline Depression & 1.73 & .51 & 1.87 & .57 & $70.78^{* * *}$ \\
\hline Relationship with teachers & 11.44 & 2.64 & 11.13 & 2.39 & $29.68^{* * *}$ \\
\hline Relationship with colleagues & 12.13 & 2.35 & 11.51 & 2.43 & $134.98^{* * *}$ \\
\hline Family support & 24.24 & 6.26 & 23.53 & 6.60 & $23.35^{* * *}$
\end{tabular}

Table 4. Mean differences between the gender of the participants Note. ${ }^{* * *} p<.001$

Through the analysis of Table 5, it is possible to verify statistically significant differences regarding the age of the participants in relation to the variables of mental health and interpersonal relationships. In general, younger students (aged 12 or younger) have more positive values in terms of mental health and relationships with family, teachers and colleagues when compared to older students (aged 13 or older). There is an exception in relation to anxiety/stress, which presents higher values in the younger student group (aged 12 years or less).

\begin{tabular}{l|c|c|c|c|c|c|c} 
& \multicolumn{2}{|c|}{$\begin{array}{c}\text { Up to } 12 \\
\text { years }\end{array}$} & \multicolumn{2}{c|}{$\begin{array}{c}\text { Between } 13 \\
\text { and } 15\end{array}$} & \multicolumn{2}{c|}{$\begin{array}{c}16 \text { years or } \\
\text { older }\end{array}$} & \multirow{2}{*}{$F$} \\
\cline { 1 - 6 } & $M$ & $S D$ & $M$ & $S D$ & $M$ & $S D$ & \\
\hline Psychological symptoms & 16.43 & 3.60 & 15.06 & 4.27 & 14.28 & 4.29 & $157.02^{* * *}$ \\
\hline Physical symptoms & 30.13 & 4.72 & 28.56 & 5.77 & 27.28 & 5.84 & $145.40^{* * *}$ \\
\hline Anxiety_stress & 2.98 & .48 & 2.71 & .66 & 2.82 & .66 & $15.63^{* * *}$ \\
\hline Depression & 1.64 & .48 & 1.77 & .54 & 1.87 & .56 & $16.29^{* * *}$ \\
\hline Relationship with teachers & 12.30 & 2.20 & 10.96 & 2.54 & 10.75 & 2.49 & $271.20^{* * *}$ \\
\hline Relationship with colleagues & 12.15 & 2.21 & 11.83 & 2.46 & 11.38 & 2.47 & $54.04^{* * *}$ \\
\hline Family support & 25.58 & 5.52 & 23.70 & 6.50 & 22.31 & 6.84 & $136.19^{* * *}$
\end{tabular}

Table 5. Mean differences between the age of the participants

Note. ${ }^{* * *} p<.001$ 
The explanatory model of the factors of mental health and interpersonal relationships that helps to explain psychological symptoms is robust $[F=359.34$ (7,4098), p<.001] and explains 38\% of the variance (Table 6).

\begin{tabular}{l|r|r|r|r} 
& \multicolumn{2}{|c|}{ Unstandardised coefficients } & $\begin{array}{c}\text { Standardised } \\
\text { coefficients }\end{array}$ & \\
\hline & \multicolumn{1}{|c|}{$\mathrm{B}$} & \multicolumn{1}{|c|}{$S E$} & \multicolumn{1}{|c}{$\beta$} & \multicolumn{1}{c}{$t$} \\
\hline (Constant) & 20.96 & .71 & & $29.63^{* * *}$ \\
\hline Age & -.03 & .03 & -.01 & -1.09 \\
\hline Gender & -1.63 & .11 & -.19 & $-15.06^{* * *}$ \\
\hline Anxiety, stress & -.72 & .11 & -.11 & $-6.83^{* * *}$ \\
\hline Depression & -2.94 & .13 & -.38 & $-22.94^{* * *}$ \\
\hline Family support & .09 & .01 & .13 & $9.52^{* * *}$ \\
\hline Relationship with colleagues & .08 & .02 & .05 & $3.37^{* *}$ \\
\hline Teachers relationship & .10 & .02 & .06 & $4.36^{* * *}$
\end{tabular}

Table 6. Linear regression of psychological symptoms Note. ${ }^{* * *} p<.001 ;{ }^{* *} p<.01$;

The explanatory model of the factors of mental health and interpersonal relationships that helps explain the physical symptoms is adequate $[F=226.04$ ( 7 , 4098), $p<.001]$ and explains $28 \%$ of the variance (Table 7 ).

\begin{tabular}{|c|c|c|c|c|}
\hline & \multicolumn{2}{|c|}{ Unstandardised coefficients } & \multirow{2}{*}{$\begin{array}{c}\text { Standardised } \\
\text { coefficients }\end{array}$} & \multirow[b]{2}{*}{$t$} \\
\hline & B & $S E$ & & \\
\hline (Constant) & 35.41 & 1.03 & & $34.49^{* * *}$ \\
\hline Age & -.19 & .04 & -.06 & $-4.49^{* * *}$ \\
\hline Gender & -2.11 & .16 & -.18 & $-13.39^{* * *}$ \\
\hline Anxiety, stress & -.54 & .15 & -.06 & $-3.56^{* * *}$ \\
\hline Depression & -3.04 & .19 & -.29 & $-16.33^{* * *}$ \\
\hline Family support & .15 & .01 & .17 & $11.12^{* * *}$ \\
\hline Relationship with colleagues & .08 & .03 & .03 & $2.34^{*}$ \\
\hline Relationship with teachers & .14 & .03 & .06 & $4.09^{* * *}$ \\
\hline
\end{tabular}

Table 7. Linear regression of physical symptoms

Note. ${ }^{* * *} p<.001 ;{ }^{*} p<.05$

The female gender, high values of depression followed by less support from the family have a strong contribution to the explanation of psychological and 
physical symptoms. Comparing the results of the regressions, it is possible to verify that the variance explained by gender and by depression is higher in the case of psychological symptoms when compared to physical symptoms, and that the variance explained by family relationship is higher in the case of physical symptoms when compared with psychological symptoms.

\section{Discussion}

The results obtained help to understand and characterize the impact of factors of mental health and interpersonal relationships on physical and psychological symptoms in adolescents. According to these results, it is possible to verify that the participants reveal positive values regarding the social support (i.e. relationship with family, teachers and colleagues) and moderate/low values of physical and psychological symptoms and depression. In terms of anxiety/stress the values are moderate, presenting an average of 2.76 in a range of 1 to 4 . Most adolescents have a positive or moderate perception of their well-being and social relationships. However, a worrying minority presents physical and psychological symptoms, dissatisfaction with life, persistent concerns and anxiety (Gaspar et al., 2012; Matos et al., 2018).

The factors related to the mental health and the interpersonal relationships variables under study present a statistically significant correlation. We emphasize the strong and positive correlation between physical symptoms and psychological symptoms, the negative correlation between low level of psychological symptoms and anxiety/stress and depression, the negative correlation between low level of physical symptoms and depression and the strong and positive correlation between anxiety/stress and depression.

Social relations and social support are very important aspects for the children and adolescents' adjusted and positive development, namely the relationships they develop with their family, colleagues and teachers, as well as the perception of belonging and social and school competence (Gaspar, Matos, Foguet al., 2010; Lee \& Goldstein, 2016; Taylor et al., 2015; Turner \& Brown, 2010; Varga \& Zaff, 2017).

Regarding the social relationships, this study highlights a positive correlation between the family support and a low level of physical and psychological symptoms and a negative correlation between a low level of family support with anxiety/stress and depression. The positive correlation between the relationship with teachers and the relationship with colleagues is also highlighted.

Positive social relationships with the various actors that are present in the different contexts in which the adolescents' are inserted (i.e. family, teachers, colleagues) can function as protective factors in terms of the development of physical and psychological symptoms, as well as regarding a better management of stress situations (Eom et al., 2012; Fuller-Iglesias et al., 2015; Liu et al., 2016; 
Nguyen et al., 2016; Tahir et al., 2015). Furthermore, positive social relationships are associated with lower levels of psychological distress and negative affect (Nguyen et al., 2015).

Gender and age differences were found regarding the variables related to mental health and interpersonal relationships. In general, girls show values in relation to physical and psychological symptoms, anxiety/stress and depression that are less positive when compared to boys. Older adolescents show values that are less positive in the same variables, except for anxiety/stress, which presents higher values in younger adolescents. In the same sense, girls and older adolescents have less positive values with regard to relationships with family, teachers and colleagues, which is in line with the evidence present in the literature. (Gaspar \& Matos, 2017; Gaspar, Matos, Ribeiro et al., 2010; Matos et al., 2018; Matos et al., 2020).

The explanatory models for mental health and interpersonal relationships that help to explain psychological and physical symptoms are robust. The female gender and higher values of depression followed by less support from the family are factors that make a strong contribute to the explanation of the psychological and physical symptoms.

Comparing the results of the study of physical and psychological symptoms, we find that the variance explained by gender and by depression is higher in the case of psychological symptoms when compared with physical symptoms. The variance explained by family relationship is higher in the case of physical symptoms when compared with psychological symptoms. A relevant percentage of adolescents often have physical symptoms, such as headache and stomach pain and psychological symptoms, such as sadness and irritation (Matos et al., 2018).

The present study reinforces the relationship between physical and psychological symptoms and mental health. Adolescents who have more physical and psychological symptoms also show more symptoms related to anxiety and depression. It also illustrates the relationship between symptoms and interpersonal relationships. The better the interpersonal relationships with the family, colleagues and teachers, the less physical and psychological symptoms are reported. Therefore, the quality of social relationships has an impact on the adolescents' mental health and adjustment (Camacho et al., 2017; Fontes, et al., 2012; Marques, Lopez et al., 2015; Matos et al., 2017; Tomé et al., 2018).

The relationship with the family is the one that appears most strongly related to the symptoms. The relationship with peers becomes increasingly important during adolescence, but the relationship with parents and the family support remains essential for the children's positive and adjusted development (Angley et al., 2015; Armstrong et al., 2005; Gaspar \& Matos, 2017; Gaspar, Matos, Foguet et al., 2010).

This study identifies a positive relationship between mental health (less physical and psychological symptoms, depression and anxiety) and positive relationships with family, colleagues and teachers, as well as gender and age specificities. 
These results have important implications in terms of public policies for the family and the school. In a time where families report difficulties raising children and schools report problems motivating them, public policies more than ever need to be family friendly (in order to enable natality raise) and they also need to focus in education and in the school contexts as a priority. In Portugal this issue is of upmost importance because we know from previous studies within this survey that Portuguese children are not too fond of schools, specially of classes, and they report a high stress related to school matters (Gaspar et al., 2020).

Mental health is an essential basis for an adjusted functioning, both at the individual and at the community level. The evidence highlights the existence of a relationship between mental health and numerous factors related to the adolescents' development, such as better health status, better academic results, more adjusted and closer interpersonal relationships, more adequate parenting and better quality of life (Chan, 2010; WHO, 2004).

In the current times, where all over the world students are returning to school after a few months at home because of the COVID-19 pandemic, the issue of mental health has really become a top priority: for all students who had a bad time confining in vulnerable situations (e.g. poverty, violence, low housing conditions, chronic health condition, mental health conditions), for those who fear coming back because of bullying situations or fear of the risk of contagion, for those who had a bad time getting adequate clinical care during the lockdown.

The current results also highlight the fact that both mental and physical health seem rather gendered, with boys and girls reporting different health conditions, and girls being always more affected by mental health issues, such as anxiety and depression. Also, the current results highlight that is seems that "the older the worst", and this is a critical issue that has been reported several times in all our studies (Gaspar et al., 2019). Tailored interventions trying to mitigate gender and age issues during adolescence should be a central topic in the educational public policies.

\section{REFERENCES}

Allen, K. A., \& McKenzie, V. L. (2015). Adolescent mental health in an Australian context and future interventions. International Journal of Mental Health, 44(12), 80-93. https://doi.org/10.1080/00207411.2015.1009780

Angley, M., Divney, A., Magriples, U., \& Kershaw, T. (2015). Social support, family functioning and parenting competence in adolescent parents. Maternal and child health journal, 19(1), 67-73. https://doi.org/10.1007/s10995-0141496-x

Armstrong, D., Price, D., \& Crowley, T. (2015). Thinking it through: a study of how pre-service teachers respond to children who present with possible 
mental health difficulties. Emotional and Behavioural Difficulties, 20(4), 381397. https://doi.org/10.1080/13632752.2015.1019248

Armstrong, M.I., Birnie-Lefcovitch, S., \& Ungar, M.T. (2005). Pathways Between Social Support, Family Well Being, Quality of Parenting, and Child Resilience: What We Know. Journal of Child and Family Studies 14, 269-281. https://doi.org/10.1007/s10826-005-5054-4

Berger, C., Alcalay, L., Torretti, A., \& Milicic, N. (2011). Socio-emotional wellbeing and academic achievement: Evidence from a multilevel approach. Psicologia: reflexâo e crítica, 24(2), 344-351.

Bronfenbrenner, U. (2005). The bioecological theory of human development. In U. Bronfenbrenner (Ed.), Making human beings human: Bioecological perspectives on human development (pp. 3-15). Sage Publications.

Camacho, I., Matos, M. G., Tomé, G., Reis, M., Jiménez-Iglesias, A., Moreno, M.C., \& Galvão, D. (2017). Brothers and Sisters - "More" is Better? Effects on School, Violence and Health. World Journal of Educational Research, 4(2), 313-326. https://doi.org/10.22158/wjer.v4n2p313

Caprara, G., \& Steca, P. (2005). Affective and social self-regulatory efficacy beliefs as determinants of positive thinking and happiness. European Psychologist, 10(4), 275-286.

Chan, M. (2010). Mental health and development: targeting people with mental health conditions as a vulnerable group. World Health Organization. https:// www.who.int/mental_health/policy/mhtargeting/development_targeting_ mh_summary.pdf

Eom, C. S., Shin, D. W., Kim, S. Y., Yang, H. K., Jo, H. S., Kweon, S. S., Kang, Y. S., Kim, J. H., Cho, B. L., \& Park, J. H. (2012). Impact of perceived social support on the mental health and health-related quality of life in cancer patients: results from a nationwide, multicenter survey in South Korea. PsychoOncology, 22(6), 1283-1290. http://doi.org/10.1002/pon.3133

Feeney, B. C., \& Collins, N. L. (2014). A theoretical perspective on the importance of social connections for thriving. In M. Mikulincer \& P. R. Shaver (Eds.), The Herzliya series on personality and social psychology. Mechanisms of social connection: From brain to group (p. 291-314). American Psychological Association. https://doi.org/10.1037/14250-017

Fontes, M., Rivera, H., Peñaloza, J., Cedeno, M., \& Rodríguez-Orozco, A. (2012). Family functioning and their relationship with social support networks in a sample of families in the city of Morelia, Mexico. Salud Mental, 35(2), 147-154.

Fuller-Iglesias, H. R., Webster, N. J., \& Antonucci, T. C. (2015). The complex nature of family support across the life span: Implications for psychological 
well-being. Developmental psychology, 51(3), 277. http://doi.org/10.1037/ $\underline{\mathrm{a} 0038665}$

Gaspar, T., Tomé, G., Ramiro, L., Almeida, A. \& Matos, M. (2020). Ecossistemas de aprendizagem e bem-estar: fatores que influenciam o sucesso escolar. Psicologia, Saúde \& Doenças, 21(2), 462-481 http://dx.doi.org/10.15309/ 20psd210221

Gaspar, T., Tomé, G., Gómez-Baya, D., Guedes, F. B., Cerqueira, A., Borges, A., \& Matos, M. G. (2019). O bem-estar e a saúde mental dos adolescentes portugueses. Revista de Psicologia da Criança e do adolescente, 10(1), 17-28.

Gaspar, T., \& Matos, M. G. (2017). Parenting practices: parent's perception of the impact in children psychological wellbeing. SM Journal of Family Medicine, 1(1), 1-6.

Gaspar, T., Matos, M. G., Foguet, J., Ribeiro, J. L., \& Leal, I. (2010). Parent-child perceptions of quality of life: Implications for health intervention. Journal of Family Studies, 16(2), 143-154. https://doi.org/10.5172/jfs.16.2.143

Gaspar, T., Matos, M. G., Ribeiro, J. L., Leal, I., Erhart, M., \& RavensSieberer, U. (2012). Health-related quality of life in children and adolescents: subjective wellbeing. Spanish Journal of Psychology, 15(1), 177-186. https:// doi.org/10.5209/rev_SJOP.2012.v15.n1.37306

Gaspar, T., Matos, M. G., Ribeiro, L. J., Leal, I. \& Ferreira, A. (2009). Healthrelated quality of life in children and adolescents and associated factors. Journal of Cognitive and Behavioral Psychotherapies, 9(1), 33-48.

Gaspar, T., Matos, M., Ribeiro, J. L., Leal, I., Erhart, M., \& Ravens-Sieberer, U. (2010). Kidscreen: Quality of life in children and adolescents. Journal of Child and Adolescent Psychology, 1, 49-64.

Hattie, J. (2009). Visible learning: A synthesis of over 800 meta-analyses relating to achievement. Routledge.

Hobfoll, S. E. (2002). Social and psychological resources and adaptation. Review General Psychology, 6(4), 307-324. http://doi.org/10.1037/10892680.6.4.307

Holt-Lunstad, J., \& Uchino, B. M. (2015). Social support and health. In K. Glanz, B. K. Rimer, \& K. Viswanath (Eds.), Health Behavior - Theory, research and practice (5th ed.). John Wiley \& Sons

Inchley, J. C., Currie, D. B., Young, T., Samdal, O., Torsheim, T., Augustson, L., Mathison, F., Aleman-Diaz, A., Molcho, M., Weber, M. \& Barnekow, V. (Eds.) (2016). Growing up unequal: gender and socioeconomic differences in young people's health and well-being: Health Behaviour in School-aged Children 
(HBSC) study: international report from the 2013/2014 survey. World Health Organization (WHO) Regional Office for Europe.

Kong, F., Ding, K., \& Zhao, J. (2015). The relationships among gratitude, selfesteem, social support and life satisfaction among undergraduate students. Journal of Happiness Studies, 16(2), 477-489. http://doi.org/10.1007/s10902014-9519-2

Lee, C. Y. S., \& Goldstein, S. E. (2016). Loneliness, stress, and social support in young adulthood: Does the source of support matter? Journal of youth and adolescence, 45(3), 568-580. http://doi.org/10.1007/s10964-015-0395-9

Lewis, A. D., Huebner, E., Malone, P. S., \& Valois, R. F. (2011). Life satisfaction and student engagement in adolescents. Journal of Youth and Adolescence, 40, 249-262. https://doi.org/10.1007/s10964-010-9517-6.

Liu,L.,Gou,Z., \&Zuo,J.(2016).Socialsupportmediateslonelinessanddepression in elderly people. Journal of health psychology, 21(5),750-758. http://doi.org/10. $1177 / 1359105314536941$

Marques, S. C., Lopez, S. J., Fontaine, A. M., Coimbra, S., \& Mitchell, J. (2015). How much hopeisenough? Levelsof hopeand students' psychologicaland school functioning. Psychology in the Schools, 52, 325-334. https://doi.org/10.1002/ pits.21833.

Matos, M. G., \& Equipa Aventura Social. (2018). A Saúde dos Adolescentes após a Recessão - Dados nacionais do estudo HBSC de 2018 ebook. www.aventurasocial. com

Matos, M. G., Gaspar., T., \& Equipa Aventura Social. (2020). Estudo Health Behaviour in School-aged Children (HBSC/OMS) Internacional - 2018 (ebook). www.aventurasocial.com

Matos, M. G., Camacho, I., Reis, M., Tomé, G., Branquinho, C., \& Ramiro, L. (2017). Is truth in the eyes of the beholder? Or are Portuguese schools, as viewed by Portuguese pupils, mismatching with what the educational system offers? Vulnerable Children and Youth Studies, 1-11. https://doi.org/10.1080/ 17450128.2017.1363447

Matos, M. G., Simões, C., Camacho, I., Reis, M., \& Equipa Aventura Social. (2015). Relatório do estudo HBSC 2014. A saúde dos adolescentes portugueses em tempos de recessão - Dados nacionais do estudo HBSC de 2014. Centro de Malária e outras Doenças Tropicais/IHMT/UNL e FMH/Universidade de Lisboa.http://aventurasocial.com/arquivo/1437158618_RELATORIO\%20 HBSC\%202014e.pdf

Melrose, K. L., Brown, G. D., \& Wood, A. M. (2015). When is received social support related to perceived support and well-being? When it is needed. 
Personality and Individual Differences, 77, 97-105. http://doi.org/10.1016/j. paid.2014.12.047

Mundia, L. (2013). Relationship between mental health and teaching. International Journal of Mental Health 42(2-3), 73-98. https://doi.org/10.2753/IMH00207411420205

Nguyen, A. W., Chatters, L. M., Taylor, R. J., \& Mouzon, D. M. (2016). Social support from family and friends and subjective well-being of older African Americans. Journal of happiness studies, 17(3), 959-979. http://doi. org/10.1007/s10902-0159626-8

Rook, K. S. (2015). Social networks in later life: Weighing positive and negative effects on health and well-being. Current Directions in Psychological Science, 24(1), 45-51. http://doi.org/10.1177/0963721414551364

Tahir, W. B. E., Inam, A., \& Raana, T. (2015). Relationship between social support and self-esteem of adolescent girls. IOSR Journal of Humanities and Social Science (IOSR-JHSS), 20(2), 42-46. http://doi.org/10.9790/083720254246

Taylor, Z. E., Conger, R. D., Robins, R. W., \& Widaman, K. F. (2015). Parenting practices and perceived social support: longitudinal relations with the social competence of Mexican-origin children. Journal of Latinalo psychology, 3(4), 193-208. https://doi.org/10.1037/lat0000038

Thoits, P.A.(2011). Mechanismslinkingsocialtiesandsupporttophysicalandmental health. Journal of health and social behavior, 52(2), 145-161. http://doi.org/10. 1177/0022146510395592

Tomé, G., Almeida, A., Ramiro, L., Gaspar, T., \& Matos, M. G. (2020 in press). Intervention in Schools promoting mental health and well-being: a systematic review. Global Journal of Community Psychology Practice.

Tomé, G., Matos, M.G., CamachoI., Gomes, P., Reis, M., \& Branquinho, C. (2018). Mental health promotion in school context - validation of the Es' cool scale for teachers. Journal of Psychiatry and Behavioral Sciences, 2, 1-11. http://doi.org/ 10.33582/2637-8027/1009

Turner, R. J., \& Brown, R. L. (2010). Social support and mental health. In T. L. Scheid \& T. N. Brown, A handbook for the study of mental health (pp. 200212). Cambridge University Press.

Umberson, D., \& Montez, J. K. (2010). Social relationships and health: a flashpoint for health policy. Journal of Health and Social Behavior, 51(S), S54-S66. https://doi.org/10.1177/0022146510383501

Varga, S. M., \& Zaff, J. F. (2017). Webs of support: An integrative framework of relationships, social networks, and social support for positive youth 
development. Adolescent Research Review, 3(1), 1-11. http://doi.org/ 10.1007/s40894-017-0076-x

World Health Organization. (2004). Promoting mental health: concepts, emerging evidence, practice (Summary Report). https:/www.who.int/mental_health/ evidence/en/promoting_mhh.pdf 
